\title{
Comparison between Composite Column Using Limestone and Basalt Concrete
}

\author{
Hamadallah Al-Baijat ${ }^{{ }^{*}}$, Andrea Benedetti ${ }^{2}$ \\ ${ }^{1}$ Department of Civil Engineering, Tafila Technical University, Tafila, Jordan \\ ${ }^{2}$ University of Bologna, Bologna, Italy \\ Email: *albaijath@yahoo.com
}

Received November 13, 2012; revised December 10, 2012; accepted December 26, 2012

\begin{abstract}
This research is conducted to study the experimental behavior of composite steel-concrete columns with basalt additives. Various percentages of basalt are added to the concrete mixes to investigate its effect on the total axial compressive capacity of the columns. Expected failure scenarios of the columns are: concrete compressive failure, buckling of steel section, and de-bonding between steel and concrete sections. A conventional limestone composite column was used as base mix. The results of the study indicate a significant improvement in structural behavior and strength of the columns by increasing the percentage of basalt content.
\end{abstract}

Keywords: Composite Column; Basalt Mix; Jordan

\section{Introduction}

Composite columns using limestone were widely used from early 1900s. However, none or very little research conducted for using basalt in composite columns. Viest in his 1960 review of research, notes that the important factor in composite actions is the bond between concrete and steel [1].

The steel-concrete composite column is a new composite member that can achieve constructability and economy by filling the empty space in the steel H-flange with concrete. Composite columns are constructed with rolled or built-up steel section. The resulting members are able to support significantly higher loads than reinforced concrete columns of the same sizes.

A structural member composed of two or more dissimilar materials joined together (to act as a unit in which the resulting system) is stronger than the sum of its parts. An example in civil structures is the steel-concrete composite column in which a steel wide-flange shape (I or W shape) is filled with various percentages of basalt to be compared with base limestone concrete mix. Basalt is hard, dense volcanic igneous rock that can be found in most countries across the world.

Basaltic rocks are available in Jordan in many places especially in the Northeastern volcanic Plateau in Harrat Ash Shaam, Asi and Shalabi, 2005 [2]. Basalt is used in many countries especially in highway and airfields pavement construction (Rodsenbaum and Skene, 1995). Jor-

"Corresponding author. dan has also a number of quarries and crushers equipped with advanced technologies and machinery to crush basaltic rocks into construction size aggregates. In conventional concrete mixes used in the construction industry in Jordan; it is customary to use limestone aggregates which are also available in great abundance. Basaltic rock aggregates are similar to limestone aggregates in many aspects [3]. Table 1 shows the key properties of limestone and basalt aggregates in Jordan. The basalt aggregates are higher in specific gravity, and lower in absorption and abrasion loss values [3]. Based on this comparison, it is clearly obvious that basalt is likely to be more suitable than limestone for use in concrete mixes and this research will investigate this matter. In order to accomplish this objective, the researcher has devised an elaborate laboratory testing program that included conventional limestone mixes with zero $\%, 25 \%, 50 \%, 75 \%$ and $100 \%$ basalt. For the purpose of comparison, samples from each mix were then tested in the laboratory to determine key mix properties.

\section{Experimental Program}

The basalt aggregates used in this research were tested for chemical composition at the Department of Chemistry of the University of Jordan by using the X-Ray Fluorescence (XRF) test. The results of this test are summarized in Table 2. Also the mechanical properties of the basalt aggregate were conducted as shown in Table 3. The results of three specimens for each group were averaged 
Table 1. Key properties of limestone and basalt aggregates used in Jordan (Courtesy of Dr. Zuhair Samarah and engineer Jamil Wrekat) [4].

\begin{tabular}{ccccc}
\hline $\begin{array}{c}\text { Aggregate } \\
\text { Property }\end{array}$ & $\begin{array}{c}\text { (Fine) } \\
\text { Basalt }\end{array}$ & $\begin{array}{c}\text { (Coarse) } \\
\text { Basalt }\end{array}$ & $\begin{array}{c}\text { (Fine) } \\
\text { Limestone }\end{array}$ & $\begin{array}{c}\text { (Coarse) } \\
\text { Limestone }\end{array}$ \\
\hline $\begin{array}{c}\text { (Apparent) } \\
\text { Specific Gravity }\end{array}$ & 2.943 & 2.917 & 2.673 & 2.626 \\
$\begin{array}{c}\text { SSD } \\
\text { Specific Gravity } \\
\quad 2.843\end{array}$ & 2.814 & 2.605 & 2.552 \\
$\begin{array}{c}\text { DRY } \\
\text { Specific Gravity } \\
\text { Absorption \% }\end{array}$ & 2.791 & 2.765 & 2.558 & 2.508 \\
Abrasion \% & 25.9 & 24.4 & 35.0 & 34.8 \\
\hline
\end{tabular}

Table 2. Chemical composition of basaltic aggregates as determined By X-Ray fluorescence test (X.R.S) \% [4].

\begin{tabular}{cc}
\hline $\mathrm{CO}_{2}$ & 1.0 \\
$\mathrm{Na}_{2} \mathrm{O}$ & 2.97 \\
$\mathrm{MgO}$ & 8.56 \\
$\mathrm{Al}_{2} \mathrm{O}_{3}$ & 14.3 \\
$\mathrm{SiO}_{2}$ & 45.9 \\
$\mathrm{P}_{2} \mathrm{O}_{5}$ & 0.372 \\
$\mathrm{SO}_{3}$ & 0.0 \\
$\mathrm{Cl}$ & 0.0 \\
$\mathrm{~K}_{2} \mathrm{O}$ & 0.861 \\
$\mathrm{CaO}^{2}$ & 11.1 \\
$\mathrm{TiO}_{2}$ & 2.25 \\
$\mathrm{MnO}$ & 0.174 \\
$\mathrm{Fe} \mathrm{O}_{3}$ & 1.22 \\
$\mathrm{SrO}$ & 0.0 \\
\hline
\end{tabular}

because their graphs are almost identical. The average deflections and strains represent one curve for each group of three specimens.

It is obvious from Table 3 that the strength of the cubes increases gradually as the percentage of basalt increases. The dimensions of the cube were $150 \mathrm{~mm} \times 150$ $\mathrm{mm} \times 150 \mathrm{~mm}$.

The first author conducted laboratory tests on 18 columns. The chart in Figure 1 shows the diagram of experimental program in this investigation. Five design mixes were used including limestone as base mix, with $25 \%, 50 \%, 75 \%$, and $100 \%$ basalt. Three steel columns were used as reference. Figure 1 shows percentages of basalt in the different mixes of composite columns. The cross section of all specimens was $80 \mathrm{~mm} \times 160 \mathrm{~mm}$, for the width and depth and their height was $1400 \mathrm{~mm}$, as shown in Figure 2. 2.

The geometry of the steel section was shown in Figure

\section{Laboratory Procedure}

Five mixes were prepared; namely limestone $(0 \%$ basalt as base mix), $25 \%, 50 \%, 75 \%$, and $100 \%$ basalt. The composition of each mix is presented in Table 4 [4]. The

Table 3. Compressive strength $(\mathrm{kN})$ versus percentage of basalt.

\begin{tabular}{ccc}
\hline $\begin{array}{c}\text { Breaking Load } \\
(\mathrm{kN})\end{array}$ & $\begin{array}{c}\text { Percentage of } \\
\text { Basalt }\end{array}$ & $\begin{array}{c}\text { Compressive Strength } \\
(\mathrm{MPa})\end{array}$ \\
\hline 750 & 0 & 33.4 \\
824 & 25 & 36.6 \\
873 & 50 & 38.8 \\
930 & 75 & 41.33 \\
1325 & 100 & 58.9 \\
\hline
\end{tabular}

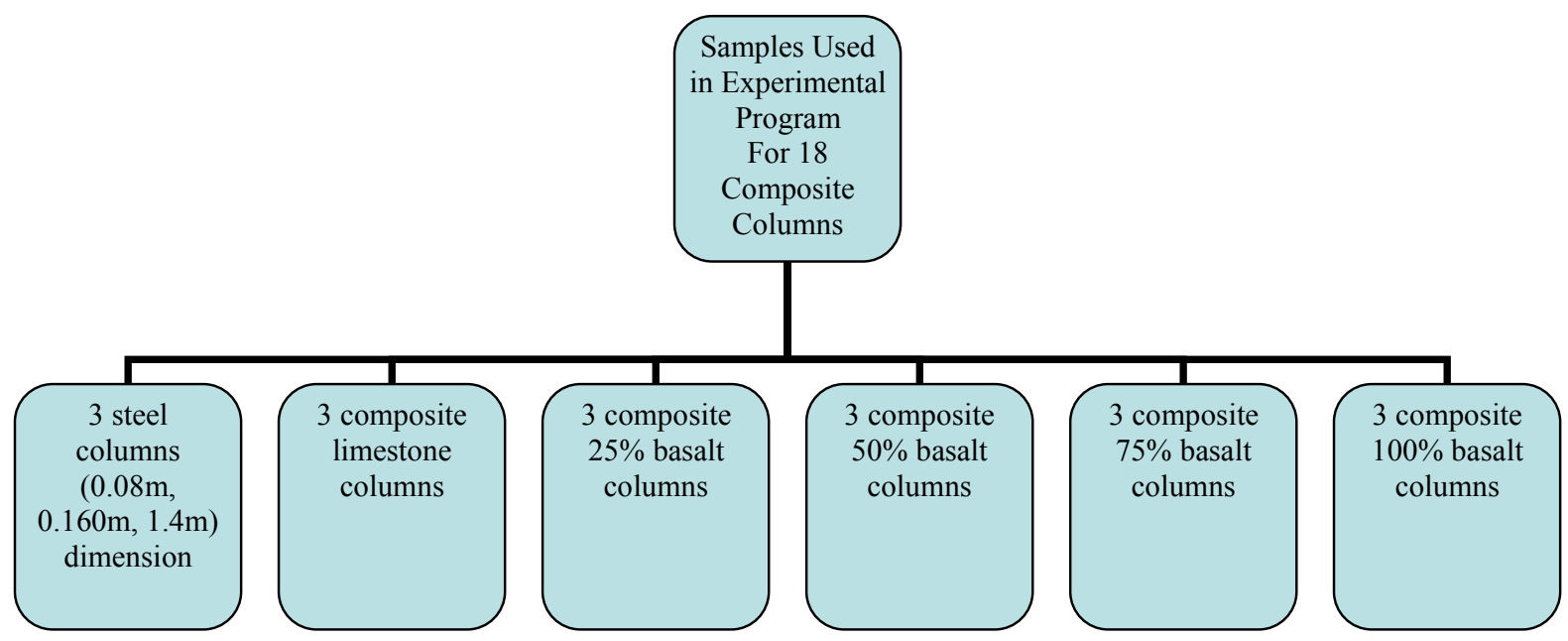

Figure 1. The chart of the experimental work used in this study. 


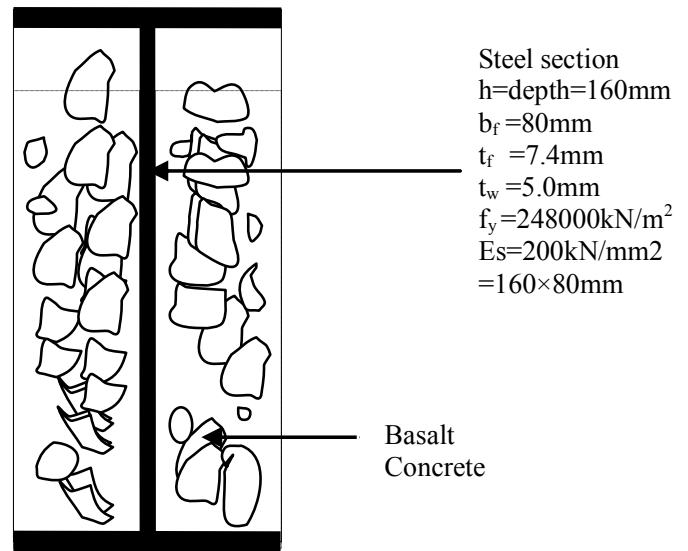

Figure 2. Typical composite cross section of the column. $L=$ $1400 \mathrm{~mm}$.

water cement ratio was 0.7 including 0.25 for hydration, and the cement was $350 \mathrm{~kg}$ per cubic meter of concrete.

\section{Results}

The center line of the composite columns were coincided with the centerline of the testing machine carefully to avoid any eccentricity and the two ends of the column were attached to the ground and to the testing machine by using rectangular steel (to avoid any horizontal movement). The mid height of the columns were marked at both sides and the dial gage (transducers) was attached to the level of marked line to measure the deflection of concentric composite columns. Similarly the other side of the column was marked, and two demic gages (transducers) (ASTM426 strain gage and BS1881:206) were attached to the column $10 \mathrm{~cm}$ above and below the center line. In this case the vertical distance between the two gages were $20 \mathrm{~cm}$. The strain and de- flection were taken from the two gages directly by using correction factor for the testing machine for both strain and deflection. The loads were applied gradually to the specimens till failure.
There was no cyclic loading applied.

After loading the column and prior to initiation of buckling, it was noted that the specimen starts to have hair horizontal cracks (parallel to the marked line). The cracks occurred in the tension region. No cracks noticed in the compression region. The load was applied gradually to the specimen and the readings were taken at various stages of loading. For this test only ascending loading was used (no cyclic loading). Out-of-plane deformation (buckling) was measured using only one dial gage since the column is short and the width is also small. The set-up of the specimen is shown in Figures $\mathbf{3}$ and $\mathbf{4}$ with strain and deflection gages attached. The strains versus loads are shown for various percentage of basalt in Table 5 and Figure 5. As the load increases; the strain of the column increases. Each curve represents the average value for three specimens for the same load and the same percentage of basalt. The standard deviations were 0.026 and 0.076 for both deflection and strain respectively.

1) The three steel and limestone composite columns were taken in this experimental program as a base specimen. It was noticed that, compared with steel columns for $500 \mathrm{kN}$ load, the strain and buckling decreased by $13.5 \%$ and $60 \%$, respectively for $0 \%$ basalt. The results are shown in Tables 5 and $\mathbf{6}$.

2) Now the composite columns are $25 \%$ basalt and $75 \%$ limestone, the test results show significant decrease $(38 \%$ and $35 \%)$ for the strain and buckling at $600 \mathrm{kN}$ load as illustrated in Tables 5 and $\mathbf{6}$.

3 ) In this case the three composite columns are $50 \%$ basalt and $50 \%$ limestone each, and the average results are shown in Table 6 and in Figure 6 for the deflection and the results were presented in Table 5 and Figure 5 for the strain. The strain and buckling decreased by $21.8 \%$ and $16 \%$, respectively for the $700 \mathrm{kN}$ load. Load carrying capacity increases as the percentage of basalt in composite section increases (Table 7 and Figure 7).

Table 4. Percentage of basalt in composite section in the different mixes.

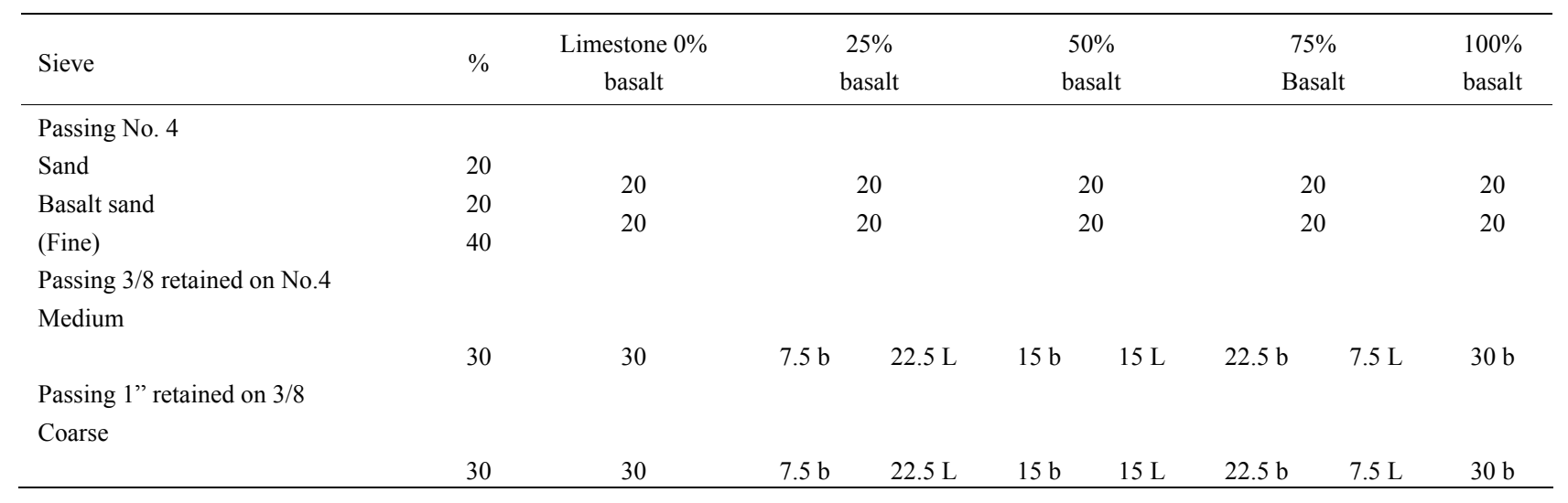

$\mathrm{b}=$ basalt, $\mathrm{L}=$ limestone. 


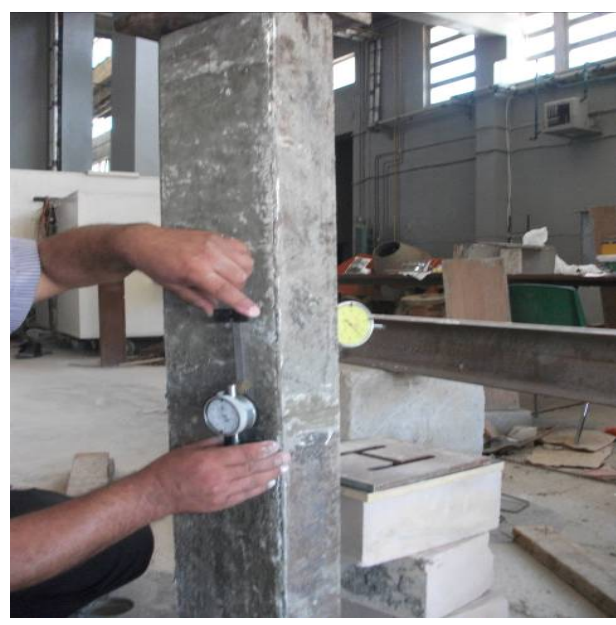

Figure 3. Composite basalt column under concentric load with strain and buckling (deflection) gages (transducers).

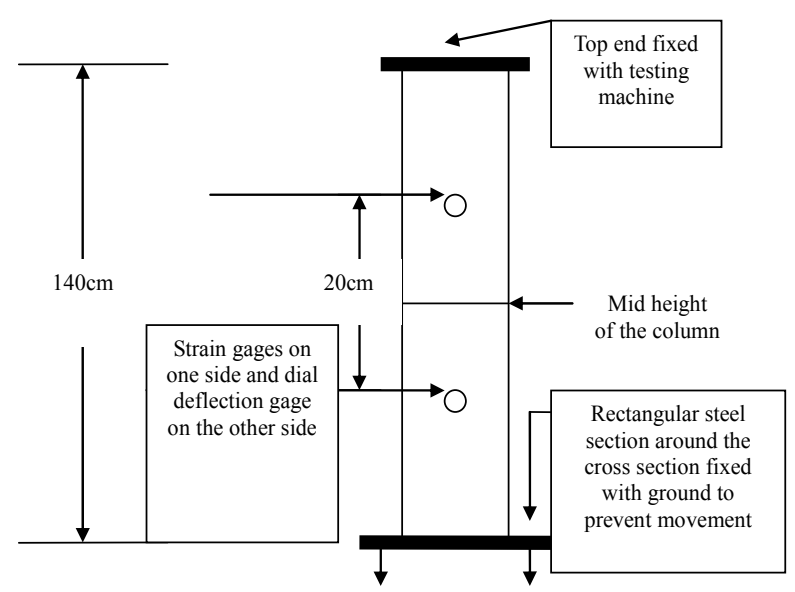

Figure 4. Location of the strain gages on one side of the column for strain.

Table 5. Load versus strain $\times 10 E-4$ for various percentages of basalt.

\begin{tabular}{|c|c|c|c|c|c|c|}
\hline Load (kN) & $\begin{array}{c}\text { Strain }(1 \times 10 \mathrm{E}-4) \\
\text { Steel }\end{array}$ & $\begin{array}{c}\text { Strain }(1 \times 10 \mathrm{E}-4) \\
0 \% \text { Basalt }\end{array}$ & $\begin{array}{c}\text { Strain }(1 \times 10 \mathrm{E}-4) \\
25 \% \text { Basalt }\end{array}$ & $\begin{array}{c}\text { Strain }(1 \times 10 \mathrm{E}-4) \\
50 \% \text { Basalt }\end{array}$ & $\begin{array}{c}\text { Strain }(1 \times 10 \mathrm{E}-4) \\
75 \% \text { Basalt }\end{array}$ & $\begin{array}{c}\text { Strain }(1 \times 10 \mathrm{E}-4) \\
100 \% \text { Basalt }\end{array}$ \\
\hline 0 & 0 & 0 & 0 & 0 & 0 & 0 \\
\hline 200 & 3.9 & 2.64 & 1.7 & 1.5 & 1.44 & 1.20 \\
\hline 400 & 7.92 & 6.32 & 4 & 3.76 & 3.68 & 2.16 \\
\hline 500 & 11.102 & 9.6 & 5.6 & 5.28 & 5.08 & 2.64 \\
\hline 600 & 19.76 & 11.76 & 7.2 & 6.8 & 6.48 & 3.36 \\
\hline 700 & - & 14.96 & 10.24 & 7.8 & 8.0 & 4.24 \\
\hline 800 & - & - & 24.26 & 10.8 & 10.40 & 5.20 \\
\hline 900 & - & - & - & - & 14.00 & 6.24 \\
\hline 1000 & - & - & - & - & 16.32 & 7.28 \\
\hline 1050 & - & - & - & - & - & 13.44 \\
\hline
\end{tabular}

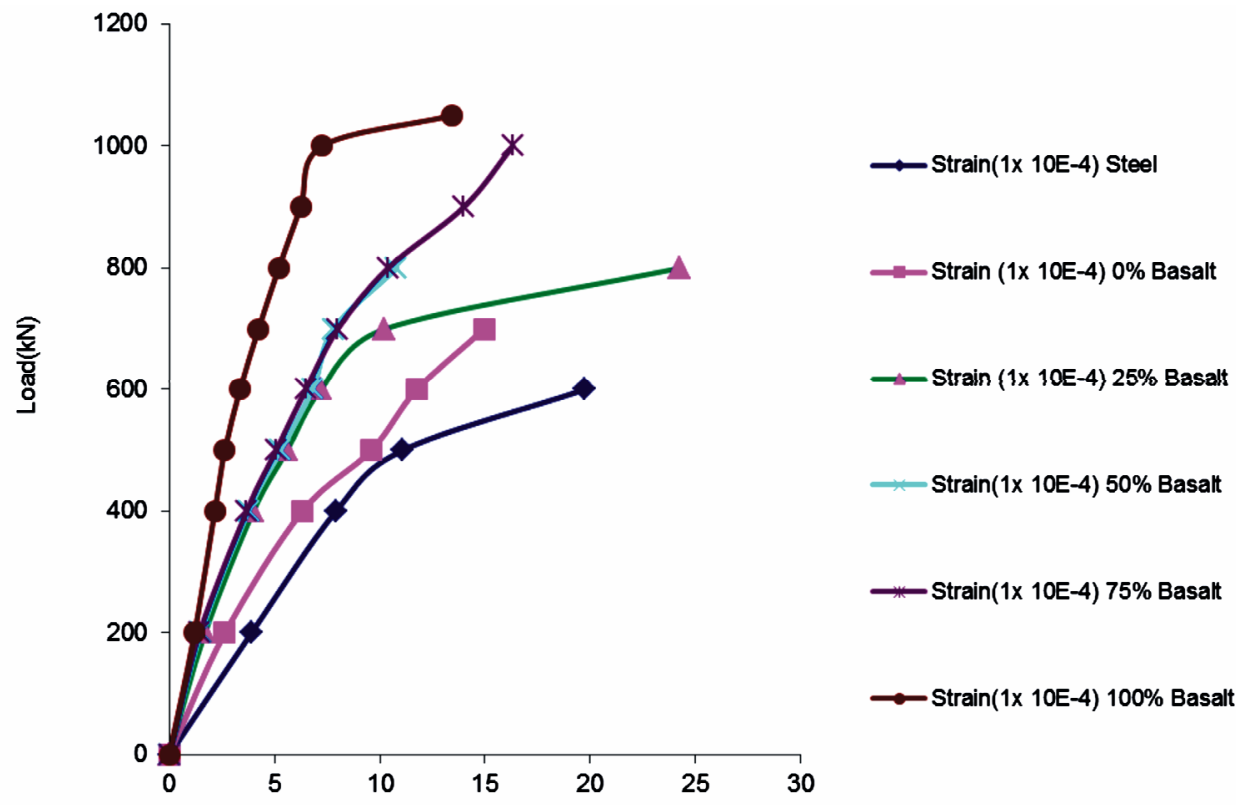

Strain(1x 10E-4)

Figure 5. Load $(\mathrm{kN})$ versus strain $(1 \times 10 \mathrm{E}-4)$. 
Table 6. Load $(\mathrm{kN})$ versus deflection $(\mathrm{mm})$ for various percentages of basalt.

\begin{tabular}{|c|c|c|c|c|c|c|}
\hline Load $(\mathrm{kN})$ & $\begin{array}{l}\text { Deflection } \\
(\mathrm{mm}) \text { Steel }\end{array}$ & $\begin{array}{c}\text { Deflection } \\
(\mathrm{mm}) 0 \% \text { Basalt }\end{array}$ & $\begin{array}{c}\text { Deflection } \\
\text { (mm) } 25 \% \text { Basalt }\end{array}$ & $\begin{array}{c}\text { Deflection } \\
(\mathrm{mm}) 50 \% \text { Basalt }\end{array}$ & $\begin{array}{c}\text { Deflection } \\
(\mathrm{mm}) 75 \% \text { Basalt }\end{array}$ & $\begin{array}{c}\text { Deflection } \\
(\mathrm{mm}) 100 \% \text { Basalt }\end{array}$ \\
\hline 0 & 0 & 0 & 0 & 0 & 0 & 0 \\
\hline 200 & 1.45 & 0.63 & 0.38 & 0.29 & 0.26 & 0.12 \\
\hline 400 & 2.84 & 0.98 & 0.65 & 0.53 & 0.40 & 0.33 \\
\hline 500 & 3.48 & 1.39 & 0.94 & 0.80 & 0.60 & 0.49 \\
\hline 600 & 5.44 & 1.88 & 1.22 & 1.08 & 0.80 & 0.68 \\
\hline 700 & - & 3.20 & 2.00 & 1.68 & 1.08 & 0.78 \\
\hline 800 & - & - & 3.44 & 3.38 & 2.65 & 2.28 \\
\hline 900 & - & - & - & - & 6.64 & 5.18 \\
\hline 1000 & - & - & - & - & 8.09 & 6.31 \\
\hline 1050 & - & - & - & - & - & 7.03 \\
\hline
\end{tabular}
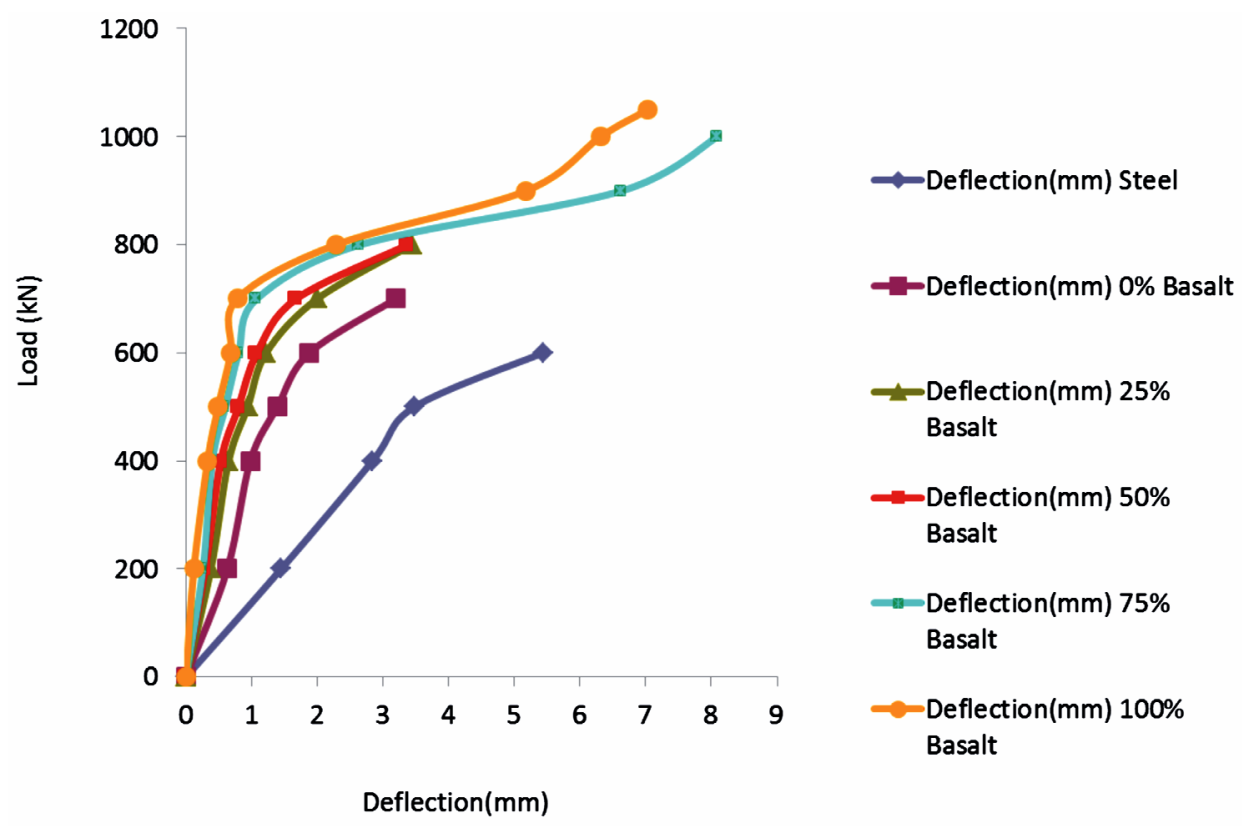

Figure 6. Load $\mathrm{kN}$ versus deflection $(\mathrm{mm})$.

Table 7. Failure load versus percentage of basalt in composite column.

\begin{tabular}{ccccccc}
\hline Basalt Percentage & Steel Section & (Limestone) & $25 \%$ & $50 \%$ & $75 \%$ & $100 \%$ \\
\hline Failure Load $(\mathrm{kN})$ & 635 & 771 & 840 & 867 & 1035 & 1075 \\
\hline
\end{tabular}

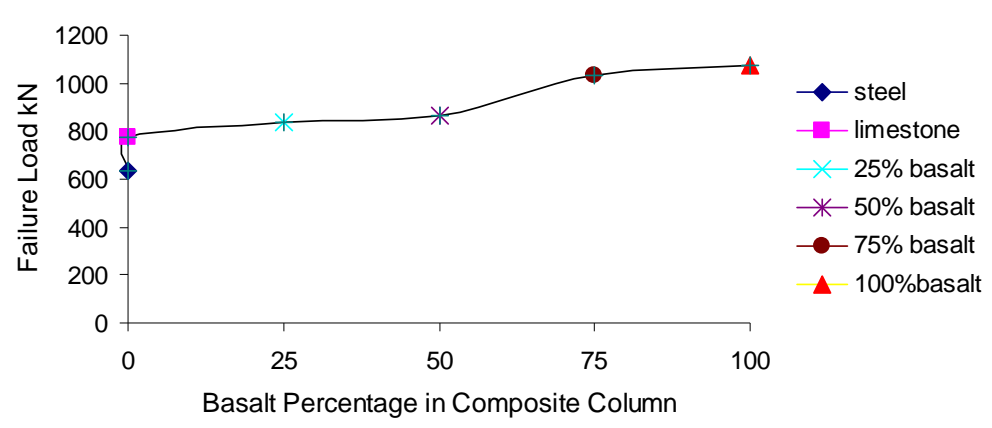

Figure 7. Failure load $\mathrm{kN}$ versus percentage if basalt in composite columa. 
The strain gages were attached to the specimen as shown in Figure 4.

4) Three composite columns were tested with $75 \%$ basalt and $25 \%$ limestone. The average tests results for deflection are shown in Table 6 and in Figure 6. The strain and buckling averages were decreased by $20.5 \%$ and $40.1 \%$ respectively. The capacity of the composite basalt columns increased by $20.6 \%$ as basalt in the mix increased from $50 \%$ to $75 \%$.

5) In the case of $100 \%$ basalt composite column, deflection decreased by $22 \%$ (Table 6 and Figure 6), and strain also decreased by $55.3 \%$ at load $1000 \mathrm{kN}$ (Table 5 and Figure 5). All the deflections results for six groups for various percentages of basalt are illustrated in Table 6 and Figure 6.

6) The results (Table 7 and Figure 7) showed significant increase in failure load as the percentage of basalt increased from $25 \%, 50 \%, 75 \%$ to $100 \%$ in composite column of about $9 \%, 12.5 \%, 34.2 \%$ and $39.4 \%$ respectively relative to the base mix (limestone). The failure load of the composite with $75 \%$ limestone and $25 \%$ basalt increased by $21 \%$ and $32 \%$ compared with steel section only.

7) Significant reduction in strain $(54 \%, 65 \%$ and $71 \%$, at 200,400 and $700 \mathrm{kN}$ respectively) took place as the composite column changed from limestone to $100 \%$ basalt as in Table 5 and Figure 5.

8) Buckling (deflection) of the composite basalt columns decreased significantly (about 64\%) compared with limestone composite columns. This reduction indicates that basalt composite columns are much stronger and more durable than those of limestone (Table 6 and Figure 6).

\section{Analysis of the Results}

The key properties investigated in this research project included:

1) Lateral buckling conducted under axial concentrated load, three steel columns $(0.08 \mathrm{~m}, 0.16 \mathrm{~m}, 1.4 \mathrm{~m})$ and three composite columns for each mix percentage total of 15 columns.

2) Strain versus load.

3) Failure load for various percentages of basalt.

As the load increased gradually from $200 \mathrm{kN}$ to 650 $\mathrm{kN}$, the deflection at various percentages shows no significant difference, but when the load increased from 650 $\mathrm{kN}$ to $1050 \mathrm{kN}$, the deflection increased for the same percentage of basalt. At the same loading, the deflection decreases as the percentage of basalt increases. This indicates that the load bearing capacity of the specimens increased as the percentage of basalt increased [5] (Table 6 and Figure 6). The experimental results show that the deflection of the steel column at $500 \mathrm{kN}$ decrease by
$60 \%$ (compared with limestone composite column), while decreased by $12 \%, 45 \%, 55 \%$, and $69 \%$ as the percentage of basalt increased (from $25 \%, 50 \%, 75 \%$ and $100 \%$ ) respectively. The strains decreased by $40.7 \%$ when comparing steel column with limestone composite column. However, as the percentage of basalt in the composite column was increased by $25 \%, 50 \%, 75 \%$ and $100 \%$, respectively for $600 \mathrm{kN}$, the strains were correspondingly decreased by $39 \%, 42 \%, 45 \%$, and $71 \%$. The failure loads increased by $17.6 \%$ when comparing steel beam with composite limestone. By increasing the percentage of basalt by $25 \%$ at each stage, the failure load increased by $8.2 \%, 11 \%, 25 \%$ and $28 \%$.

\section{Acknowledgements}

The author would like to thank the Tafilah Technical University for the financial support of this research project.

\section{Conclusions and Recommendation for Further Research}

It was noticed from the experimental work that the composite basalt column behaved better than limestone composite column. This improvement is relevant only to concentric axial compressive load conditions. Thus using composite basalt column rather than limestone column is highly recommended. To avoid any slip problems between steel and basalt concrete, the authors recommends future research on using mechanical stud connector to resist shear which may develop during bending. The stud should be attached to the web of the column to keep the bond in the composite section.

\section{REFERENCES}

[1] I. M. Viest, "Review of Research on Composite SteelConcrete Construction," Journal of the Structural Division, ASCE, Vol. 86, No. ST6, 1960, pp. 1-21; Also Transactions on ASCE, Partii, Vol. 126, 1961, pp. 1101-1123.

[2] I. M. Asi, "Evaluating Skid Resistance of Different Asphalt Concrete Mixes," Building and Environment Journal, 2005, in press.

[3] Ministry of Public Works and Housing, "Specifications for Highway and Bridge Construction, Vol. II," Ministry of Public Works and Housing of Hashemite Kingdom of Jordan, 1991.

[4] H. M. O. Al-Baijat, "The Use of Basalt Aggregates in Concrete Mixes in Jordan," Jordan Journal of Civil Engineering, Vol. 2, No. 1, 2008, pp. 63-70.

[5] K. Ibrahim, "The Geological Framework for the Harrat Ash-Shaam Basaltic Super-Group and Its Volcanotectonic Evolution," Natural Resources Authority, 1993, 33 p. 